\title{
Is God Listening to My Prayers? Initial Validation of a Brief Measure of Perceived Divine Engagement and Disengagement in Response to Prayer
}

\author{
Julie J. Exline ${ }^{1, * \mathbb{D}}$, Joshua A. Wilt ${ }^{1} \mathbb{D}$, Valencia A. Harriott ${ }^{1}$, Kenneth I. Pargament ${ }^{2}$ (D) and Todd W. Hall ${ }^{3}$ \\ 1 Department of Psychological Sciences, Case Western Reserve University, Cleveland, OH 44106-7123, USA; \\ joshua.wilt@case.edu (J.A.W.); drvalenciaharriott@gmail.com (V.A.H.) \\ 2 Department of Psychology, Bowling Green State University, Bowling Green, OH 43403-0001, USA; \\ kpargam@bgsu.edu \\ 3 Department of Psychology, Biola University, La Mirada, CA 90639, USA; todd.hall@biola.edu \\ * Correspondence: julie.exline@case.edu
}

Citation: Exline, Julie J., Joshua A. Wilt, Valencia A. Harriott, Kenneth I. Pargament, and Todd W. Hall. 2021 Is God Listening to My Prayers? Initial Validation of a Brief Measure of Perceived Divine Engagement and Disengagement in Response to Prayer. Religions 12: 80. https://doi.org/ $10.3390 /$ rel12020080

Academic Editor: Arndt Büssing

Received: 24 December 2020

Accepted: 24 January 2021

Published: 27 January 2021

Publisher's Note: MDPI stays neutral with regard to jurisdictional claims in published maps and institutional affiliations.

Copyright: (c) 2021 by the authors. Licensee MDPI, Basel, Switzerland. This article is an open access article distributed under the terms and conditions of the Creative Commons Attribution (CC BY) license (https:/ creativecommons.org/licenses/by/ $4.0 /)$
Abstract: Does God listen and respond to prayers? This project provided initial validation for a brief measure of perceived divine engagement and disengagement in response to prayer. As part of a larger project on religious/spiritual struggles among U.S. undergraduates, we used Sample $1(n=400)$ for exploratory factor analysis and Sample $2(n=413)$ for confirmatory factor analysis and initial validity testing. A two-factor model with four items per factor provided acceptable fit. On average, participants reported more divine engagement than disengagement. They endorsed items about God listening more than those about God responding. Divine engagement showed strong positive associations with religiousness and positive-valence variables involving God. Divine disengagement showed strong positive associations with variables suggesting divine struggle or distance. Importantly, both subscales also showed evidence of incremental validity: Divine engagement predicted positive-valence God variables (e.g., secure attachment, collaborative religious coping, gratitude to God, and awareness of God) even when controlling for religiousness and positive God concepts and attitudes. Divine disengagement predicted more spiritual struggles and more negative-valence and distance-related God variables (divine struggle, anxious and distant attachment, and self-directing religious coping) even when controlling for doubt about God's existence, negative God images, anger/disappointment toward God, and concern about God's disapproval. In short, this brief new measure shows promise as a tool to assess beliefs about God's responsiveness to prayer.

Keywords: religious and spiritual struggles; prayer; attachment to God; God concepts; religious coping

\section{Introduction}

When people pray, do they believe that God is listening and answering? In human relationships, a sense that the other person is hearing and responding to us is an important predictor of attachment security (Cassidy and Shaver 2016) and relationship satisfaction (Kuhn et al. 2018). Might similar dynamics exist in people's perceived relationships with God? Many people do see themselves as having a two-way, relationally engaged bond with God (Davis et al. 2013; Hall and Fujikawa 2013), one in which God speaks to them (Luhrmann 2012), helps to meet attachment needs (Granqvist et al. 2010), intervenes in their lives (Degelman and Lynn 1995; Exline et al. 2017; Ray et al. 2015), and collaborates with them in solving problems (Pargament et al. 1988; Wilt et al. 2019). Our aim for this project was to provide initial validation data for a new, brief measure of perceived divine engagement and disengagement in response to prayer. We proposed that a sense of divine engagement would emerge as an important facet of a positive, close perceived relationship with God, whereas a sense of silence or nonresponse from God would suggest a disrupted connection. 


\subsection{Conceptual Background: Perceived Relationship with God and Responses to Prayer}

Many people see God in a personal light and perceive themselves as having a relationship with God. This point has been well documented in recent years in research on topics such as attachment to God (Beck and McDonald 2004; Granqvist et al. 2010; Kirkpatrick 2005; Rowatt and Kirkpatrick 2002), object-relations approaches involving God (Hall and Edwards 2002), God images (Davis et al. 2013; Hall and Fujikawa 2013; Moriarty and Hoffman 2013), and relational spirituality (Counted et al. 2018; Davis et al. 2018; Hall 2015; Hall and Hall forthcoming; Mahoney 2010). Many researchers have also documented diverse ways that people try to communicate with God through prayer (Dein and Littlewood 2008; Ladd and Spilka 2013; Spilka and Ladd 2012; Poloma and Pendleton 1989; Poloma and Lee 2012). These topics have generated well-developed literatures within the psychology of religion and spirituality.

Our main aim here was to focus on a small piece of this extensive literature on perceived relationships and communication with God: the question of whether people believe that God is actually listening and responding to their prayers. A variety of studies have shown that people not only try to communicate with God through prayer; some also believe that God speaks to them (Dein and Cook 2015; Dein and Littlewood 2007; Harriott and Exline 2017; Poloma and Lee 2012; Luhrmann 2012; Wilt et al. 2019). As such, they may see themselves as being in a two-way conversation with God at times, as in a human relationship (Poloma and Lee 2012; Wilt et al. forthcoming).

This sense of having a two-way, collaborative relationship with God has been linked with more perceived growth in the wake of both negative life events (Pargament et al. 2000) and spiritual struggles (Exline et al. 2017; Wilt et al. 2019). However, there is no guarantee that this perceived two-way relationship will always go smoothly. Many prayers involve petitions (see, e.g., Poloma and Pendleton 1989; Spilka and Ladd 2012), thereby introducing the idea of a transaction in this relationship with God: Will God respond to my requests? (See Smith 2007, for more on how this transactional view of God may be especially relevant for American youth today).

Reflecting the potential importance of a sense of divine engagement in response to prayer, several existing measures do include items about God's responsiveness or lack of responsiveness to prayer, including the RCOPE measure of religious coping (Pargament et al. 2000), the Spiritual Dryness Scale (Büssing et al. 2013), the Prayer Experiences Scale (Dein and Littlewood 2008), measures of perceived helpful actions by God (Exline et al. 2017; Wilt et al. 2019), and the Meditative and Colloquial subscales of a measure tapping different types of prayer (Poloma and Pendleton 1989). To our knowledge, however, this concept of God's perceived engagement vs. disengagement in response to prayer has not received focused attention as a distinct construct.

\subsection{Prayers Unheard: The Potential for Divine Struggle or a Sense of Distance}

What might happen if people perceive a sense of silence from God in response to their prayers? Granted, a pursuit or embrace of silence is an important part of some types of prayer (Ladd and Spilka 2002; Poloma and Pendleton 1989), with centering prayer as one example (Fox et al. 2016). But in this project we are talking about a different sense of silence: We are referring to a perception that God might not be answering or responding to prayers. We would expect that in many cases, seeing God as being silent or unresponsive would be a source of struggle. Seeing God as distant and uninvolved is related to doubts about God's existence (Exline et al. 2015); but even those who believe strongly in God might struggle if they feel unheard or ignored. Such perceptions might fuel a sense of being abandoned or unloved by God, both of which are core facets of insecure attachment to God (Beck and McDonald 2004; Granqvist et al. 2010; Hall and Edwards 2002; Hall 2015; Kirkpatrick 2005; Rowatt and Kirkpatrick 2002) and divine struggle (Exline et al. 2014; Pargament et al. 1998, 2000; Wilt et al. forthcoming).

Studies of close interpersonal relationships can once again provide a useful parallel here. People can harm others not only through acts of commission (doing harmful things) 
but also through acts of omission (failing to do helpful or positive things; cf. Gilovich and Medvec 1995; Levine et al. 2018). In human attachment relationships, problems arise not only from active mistreatment, but also from passive neglect (Cassidy and Shaver 2016). In other contexts, people often seek out social support from others in response to important needs in their lives (Gleason and Iida 2015; McLeod et al. 2020), and when people do not listen or respond to these requests for support, they can fail to meet important needs for care, affirmation, and love. People who do not feel heard, understood, and affirmed, as though they do not have a real "voice" in a relationship, tend to feel dissatisfied, as shown in the close relationship literature (Jones et al. 2018; Kuhn et al. 2018). They may also be confused as to what a lack of response means: Does the other person not see them as important? Are they completely preoccupied with other concerns? Or might they be trying to weaken or even sever the relational bond, perhaps through angry withdrawal or rejection? In any case, a sense that the other person is not listening is likely to be related to a sense of increased distance or disruption in the relationship. We expected to see this same pattern for people's perceived relationships with God as well.

In recent years, researchers have assessed problems in people's perceived relationships with God in many ways, often using measures of anxious and avoidant (or distant) attachment to God (Beck and McDonald 2004; Hall and Edwards 2002; Hall 2015; Rowatt and Kirkpatrick 2002), divine struggle (Exline et al. 2014, 2015; Pargament et al. 1998, 2000; Wood et al. 2010), spiritual dryness (Büssing et al. 2013, 2017, 2020), and negative God concepts and images (Exline et al. 2015; Davis et al. 2013; Hall and Fujikawa 2013). (For reviews, see Exline 2013; Pargament and Exline forthcoming). Much of the work on divine struggles and anxious attachment to God has emphasized feelings of anger and disappointment toward God (Exline 2020; Exline et al. 2011, 2014; Pargament et al. 1998, 2000; Wood et al. 2010) as well as concerns about divine disapproval or punishment (e.g., Exline 2020; Exline et al. 2015, 2016; Hall and Edwards 2002; Hall 2015; Pargament et al. 1998, 2000).

Most of these measures also assess some themes related to disengagement, including a sense of abandonment by God (e.g., Beck and McDonald 2004; Büssing et al. 2013; Exline et al. 2014; Hall and Edwards 2002; Hall 2015; Pargament et al. 1998, 2000) or a sense that God is not being responsive (Beck and McDonald 2004; Büssing et al. 2013; Hall and Edwards 2002; Hall 2015; Rowatt and Kirkpatrick 2002). Some other recent mixed-methods work (Wilt et al. forthcoming) has examined themes that emerge in people's imagined conversations with God, some of which center on abandonment or uncertainty about God's response. Further, an earlier study on divine struggles (Exline et al. 2015) showed that seeing God as distant and unresponsive (at the level of a broad, general God concept) was linked with greater doubt about God's existence.

Research to date, then, has certainly addressed ideas about God seeming distant, unresponsive, or abandoning. Here our focus was more specifically on perceptions of God's responsiveness to prayer-perceptions that might prove to be important predictors or reflections of the quality of a person's perceived bond with God. Granted, some existing measures do include items about God's responsiveness (or lack of responsiveness) to prayer (e.g., Büssing et al. 2013; Hall and Edwards 2002; Pargament et al. 2000), but divine responsiveness is not the main focus of these broader measures.

\subsection{The Current Project}

In this project, our aim was to develop and examine a brief measure focusing specifically on perceptions of divine engagement and disengagement in response to one's prayers. After generating a set of face-valid items for this project and administering them to a large undergraduate sample, we split the sample to enable both exploratory factor analysis (EFA; Sample 1) and confirmatory factor analysis (CFA; Sample 2). We expected that two subscales would emerge from our eight items: one focusing on perceptions of divine engagement and the other on divine disengagement. We expected the two subscales to correlate negatively, and we expected participants to report more perceived divine 
engagement than disengagement. We also performed exploratory item-level analyses before moving on to preliminary tests of reliability and validity (including convergent, discriminant and incremental validity).

To avoid listing a long, detailed set of validity-related hypotheses here and repeating them later, we will elaborate our validity-related hypotheses in the relevant parts of the Results section. Broadly speaking, however, these were our main predictions: In terms of convergent validity, we expected that perceived divine engagement in response to prayer would correlate positively with other positive-valence variables focused on God and religion, whereas perceived divine disengagement would correlate with indicators of religious/spiritual struggle and other variables suggesting a sense of distance or conflict in one's relationship with God. We also performed tests of incremental validity by examining whether perceived divine engagement and disengagement would predict unique variance in variables focused on a personal relationship with God, even when controlling for other, more distal God-oriented variables (e.g., religiousness; belief in God; God concept; general attitudes toward God).

\section{Method: Participants, Procedure, and Creation of Two Samples}

\subsection{Participants and Procedure}

Participants were students enrolled in Introductory Psychology at three U.S. universities: a public research university in the Great Lakes region, a private research university in the Great Lakes region, and a private Christian university on the West coast. The two samples used for this project were drawn from the Fall 2013 and Spring 2014 semesters of a study entitled "Religious and Spiritual Issues in College Life," for which students completed an online survey and received partial course credit $(N=1239)$.

\subsection{Creation of Two Samples}

To create the two samples for this project, one for the exploratory factor analysis (EFA; Sample 1) and the other for the confirmatory factor analysis (CFA) and preliminary validity analyses (Sample 2), we used block randomization, going through the larger sample sequentially and assigning participants to two samples based on alternating rows ( $n=620$ for Sample 1, 619 for Sample 2).

In response to an item asking, "How often do you pray?", only those who selected "once in a while" or "often" (and not those who selected "never") were given the items on perceived divine engagement and disengagement in response to prayer. This project included only participants who reported some engagement in prayer and who were thus asked to complete the items on divine engagement and disengagement $(n=400$ in Sample $1, n=413$ in Sample 2).

Table 1 summarizes categorical demographic variables for the final versions of Samples 1 and 2. In both samples, there were approximately twice as many female as male participants. The majority identified as heterosexual, White/Caucasian/European American, and Christian. The mean age in both samples was 19.0 years $(S D=1.4$ in Sample 1, 2.0 in Sample 2). 
Table 1. Summary of Categorical Demographic Variables for Samples 1 and 2.

\begin{tabular}{|c|c|c|}
\hline Measure & $\begin{array}{l}\text { Sample } 1 \\
(n=400)\end{array}$ & $\begin{array}{c}\text { Sample } 2 \\
(n=413)\end{array}$ \\
\hline \multicolumn{3}{|l|}{ Gender } \\
\hline Male & $133(33 \%)$ & $131(32 \%)$ \\
\hline Female & $262(66 \%)$ & $279(68 \%)$ \\
\hline Transgender male & $1(0.3 \%)$ & $0(0 \%)$ \\
\hline Other & $1(0.3 \%)$ & $0(0 \%)$ \\
\hline Prefer not to say & $1(0.3 \%)$ & $0(0 \%)$ \\
\hline \multicolumn{3}{|l|}{ Sexual orientation } \\
\hline Heterosexual & $380(96 \%)$ & $388(94 \%)$ \\
\hline Homosexual (gay or lesbian) & $4(1 \%)$ & $6(2 \%)$ \\
\hline Bisexual & $7(2 \%)$ & $7(2 \%)$ \\
\hline Asexual & $2(0.5 \%)$ & $4(1 \%)$ \\
\hline Other & $4(1 \%)$ & $2(0.5 \%)$ \\
\hline Prefer not to say & $1(0.3 \%)$ & $4(1 \%)$ \\
\hline \multicolumn{3}{|l|}{ Race/ethnicity (multiple options allowed) } \\
\hline White/Caucasian/European American & $301(75 \%)$ & $292(71 \%)$ \\
\hline Asian/Pacific Islander & $37(9 \%)$ & $54(13 \%)$ \\
\hline African American/Black & $30(8 \%)$ & $36(9 \%)$ \\
\hline Latinx/Hispanic & $44(11 \%)$ & $50(12 \%)$ \\
\hline $\begin{array}{l}\text { American Indian/ Native American/Alaska } \\
\text { Native }\end{array}$ & $7(2 \%)$ & $5(1 \%)$ \\
\hline Middle Eastern & $2(0.5 \%)$ & $7(2 \%)$ \\
\hline Other/mixed & $9(2 \%)$ & $12(3 \%)$ \\
\hline Prefer not to say & $3(1 \%)$ & $1(0.2 \%)$ \\
\hline \multicolumn{3}{|l|}{ Religious affiliation } \\
\hline $\begin{array}{l}\text { Protestant, nondenominational, or } \\
\text { unspecified Christian }\end{array}$ & $277(70 \%)$ & $298(73 \%)$ \\
\hline Catholic & $93(23 \%)$ & $74(18 \%)$ \\
\hline Eastern Orthodox Christian & $2(0.5 \%)$ & $3(1 \%)$ \\
\hline Jewish & $1(0.3 \%)$ & $5(1 \%)$ \\
\hline Hindu & $2(0.5 \%)$ & $2(0.5 \%)$ \\
\hline Buddhist & $2(0.5 \%)$ & $0(0 \%)$ \\
\hline Atheist & $1(0.3 \%)$ & $3(1 \%)$ \\
\hline Agnostic & $1.5(1 \%)$ & $6(2 \%)$ \\
\hline None & $10(2 \%)$ & $10(2 \%)$ \\
\hline Other & $3(1 \%)$ & $5(1 \%)$ \\
\hline
\end{tabular}

\subsection{Measure of Perceived Divine Engagement and Disengagement}

As described in Section 2.2 above, participants who reported some engagement in prayer read the following prompt: "When you pray, how often do you perceive or experi- 
ence the following?" followed by the eight items on divine engagement and disengagement. (See Table 2 for items). These eight items were embedded in a list with five filler items and presented in random order. All items were rated as follows: $1=$ never, 2 = rarely, 3 = sometimes, 4 = often, 5 = always.

Table 2. Samples 1 and 2: Item-Level Means and Bonferroni-Corrected Comparisons on Divine Engagement and Disengagement Items.

\begin{tabular}{lll}
\hline \multicolumn{1}{c}{ Full Text for Item } & $\begin{array}{c}\text { Sample 1 } \\
\boldsymbol{M} \text { (SD) }\end{array}$ & $\begin{array}{c}\text { Sample 2 } \\
\boldsymbol{M} \text { (SD) }\end{array}$ \\
\hline belief that God is listening to the prayer & $4.0_{\mathrm{a}}(1.0)$ & $3.9_{\mathrm{a}}(1.1)$ \\
\hline belief that you have received guidance from God & $3.4_{\mathrm{b}}(1.0)$ & $3.3_{\mathrm{b}}(1.0)$ \\
\hline a sense of having an answer to the prayer & $3.1_{\mathrm{c}}(0.9)$ & $3.0_{\mathrm{c}}(0.9)$ \\
\hline $\begin{array}{l}\text { a sense that God is speaking to you (or communicating } \\
\text { in some way) }\end{array}$ & $3.0_{\mathrm{c}}(1.1)$ & $3.0_{\mathrm{c}}(1.0)$ \\
\hline a sense that God is being "silent" or unresponsive & $2.6_{\mathrm{d}}(1.1)$ & $2.7_{\mathrm{d}}(1.1)$ \\
\hline questioning whether God really hears your prayers & $2.4_{\mathrm{e}}(1.2)$ & $2.4_{\mathrm{e}}(1.2)$ \\
\hline questioning whether God is interested in your concerns & $2.3_{\mathrm{e}}(1.1)$ & $2.4_{\mathrm{e}}(1.1)$ \\
\hline belief that God is not trying to communicate with you & $2.0_{\mathrm{f}}(1.0)$ & $2.0_{\mathrm{f}}(1.0)$ \\
\hline
\end{tabular}

Note. Means with different subscripts differ at $p<0.05$ using the Bonferroni correction.

\section{Preliminary Analyses Focused on Both Samples: Inter-Item Comparisons and Correlations of the Proposed Divine Engagement/Disengagement Items}

Before moving on to our factor analyses, we began with some initial analyses to examine the proposed divine engagement and disengagement items in both samples. First, we compared ratings of the eight divine engagement/disengagement items. We made no specific predictions about item differences except one: We expected the divine engagement items (the top four items in Table 2) to be endorsed more than the divine disengagement items (the bottom four items in Table 2). In Sample 1, for these inter-item comparisons, Wilks' $\lambda=0.36, F(7,393)=99.64, p<0.001$, partial $\Omega^{2}=0.64$. In Sample 2, Wilks' $\lambda=0.38$, $F(7,406)=92.46, p<0.001$, partial $\Omega^{2}=0.62$.

Table 2 presents item-level comparisons in descending order based on means, which showed similar patterns in both samples (and no significant differences between the samples). Means with different subscripts differ at $p<0.05$ using the Bonferroni correction. As predicted, the divine engagement items were endorsed at higher levels than the divine disengagement items. In terms of inter-item differences on divine engagement, belief that God was listening to the prayer was endorsed the most, followed by belief in receiving guidance by God. Next was a sense of having an answer to the prayer and a sense that God was trying to speak or communicate (which did not differ from each other). For the divine disengagement items, the most endorsed response was a sense that God was being "silent" or unresponsive, followed by questioning whether God really hears one's prayers or is interested in them (these two items did not differ). Belief that God was not trying to communicate received the lowest endorsement.

Before moving on to our factor analytic work, we wanted to examine the bivariate correlations between items. Table 3 presents inter-item correlations for the eight engagement/disengagement items (Sample 1 above diagonal, Sample 2 below diagonal). In both samples, the items intended to assess divine engagement showed strong positive correlations with each other, but not high enough to suggest excessive redundancy. A similar pattern was found for the divine disengagement items. The divine engagement items also showed negative associations with the items designed to assess divine disengagement. Although a few large negative associations (i.e., with magnitudes greater than 0.30; see Funder and Ozer 2019) emerged between a few of the divine engagement and disengagement items, these associations made sense conceptually. For example, in both samples, a 
sense that God was listening showed a large negative correlation with questioning whether God was hearing or interested.

Table 3. Inter-Item Correlations for Divine Engagement/Disengagement: Samples $1(N=400)$ and $2(N=413)$.

\begin{tabular}{|c|c|c|c|c|c|c|c|c|}
\hline & Answer & Guidance & Listen & Speak & Silent & $\begin{array}{l}\text { Question } \\
\text { Hearing }\end{array}$ & $\begin{array}{c}\text { Question } \\
\text { Interest }\end{array}$ & $\begin{array}{c}\text { Not } \\
\text { Comm. }\end{array}$ \\
\hline Answer & 1.00 & $0.54^{* *}$ & $0.42^{* *}$ & $0.53^{* *}$ & -0.03 & $-0.17^{* *}$ & $-0.17^{* *}$ & $-0.13^{* *}$ \\
\hline Guidance & $0.57 * *$ & 1.00 & $0.59 * *$ & $0.52 * *$ & $-0.16^{* *}$ & $-0.28^{* *}$ & $-0.27^{* *}$ & $-0.23^{* *}$ \\
\hline Listen & $0.42^{* *}$ & $0.50 * *$ & 1.00 & $0.43^{* *}$ & $-0.15^{* *}$ & $-0.45^{* *}$ & $-0.35^{* *}$ & $-0.36^{* *}$ \\
\hline Speak & $0.56^{* *}$ & $0.65^{* *}$ & $0.48^{* *}$ & 1.00 & $-0.09+$ & $-0.26^{* *}$ & $-0.23^{* *}$ & $-0.16^{* *}$ \\
\hline Silent & $-0.11 *$ & $-0.21^{* *}$ & $-0.16^{* *}$ & $-0.16^{* *}$ & 1.00 & $0.38 * *$ & $0.46^{* *}$ & $0.42^{* *}$ \\
\hline $\begin{array}{l}\text { Question } \\
\text { hearing }\end{array}$ & $-0.23^{* *}$ & $-0.26^{* *}$ & $-0.36^{* *}$ & $-0.18^{* *}$ & $0.42^{* *}$ & 1.00 & $0.51^{* *}$ & $0.64^{* *}$ \\
\hline $\begin{array}{c}\text { Question } \\
\text { interest }\end{array}$ & $-0.13^{* *}$ & $-0.28^{* *}$ & $-0.32^{* *}$ & $-0.25^{* *}$ & $0.47^{* *}$ & $0.45^{* *}$ & 1.00 & $0.48^{* *}$ \\
\hline Not comm. & $-0.17^{* *}$ & $-0.24^{* *}$ & $-0.29^{* *}$ & $-0.20^{* *}$ & $0.48^{* *}$ & $0.58 * *$ & $0.44^{* *}$ & 1.00 \\
\hline
\end{tabular}

Note. Sample 1 correlations are above the diagonal; Sample 2 correlations are below. $+p<0.10 ;{ }^{*} p<0.05 ; * * p<0.01$.

Taken together, these correlational analyses clarified that the items on each proposed subscale captured a reasonable breadth of content (i.e., items were not highly redundant) while showing the potential for reasonable levels of internal consistency. Our next step was to do factor analyses to evaluate whether the divine engagement and disengagement items did indeed load onto two distinct factors. We began with the exploratory factor analysis (EFA), for which we used Sample 1.

\section{Sample 1: Method and Results}

\subsection{Method}

See Section 2.1 for recruitment details. Table 1, left column, presents demographic data for participants in Sample 1. Section 2.3 gives details on the divine engagement/ disengagement measure.

\subsection{Analysis Plan}

After performing the preliminary item-level analyses described in Section 3, we turned to our primary analyses for Sample 1: an exploratory factor analysis (EFA) of the divine engagement/disengagement items.

\subsection{Results: Exploratory Factor Analysis (EFA)}

Table 4 presents factor loadings based on an EFA with maximum likelihood extraction and direct oblimin rotation. Two factors emerged, as predicted (Factor 1: eigenvalue $=3.4$, $42.5 \%$ of variance; Factor 2: eigenvalue $=1.6,20.7 \%$ of variance), based on examination of eigenvalues and a scree plot. We assigned four items to each factor based on the loadings shown in Table 4, with the first subscale tapping divine disengagement and the second tapping divine engagement. Internal consistency ratings were moderate, though acceptable, for both subscales (divine disengagement: $\alpha=0.79$; divine engagement: $\alpha=0.80$ ). As predicted, the two subscales showed a moderate negative correlation, $r(400)=-0.36$, $p<0.001$. Ratings for divine engagement $(M=3.4, S D=0.8)$ were higher than those for divine disengagement $(M=2.3, S D=0.9), t(399)=14.99, p<0.001$, Cohen's $d=1.24$, as expected. There was one moderate cross-loading: a sense of having an answer to the prayer loaded on the disengagement factor with a magnitude of 0.267 , which makes sense given that this item focuses very directly on God answering prayers. 
Table 4. Sample 1: Loadings for Exploratory Factor Analysis (EFA) of Proposed Items on Divine Engagement and Disengagement.

\begin{tabular}{|c|c|c|}
\hline Full Text for Item & Factor 1 Loading & Factor 2 Loading \\
\hline belief that God is listening to the prayer & -0.105 & 0.736 \\
\hline belief that you have received guidance from God & 0.036 & 0.779 \\
\hline a sense of having an answer to the prayer & 0.267 & 0.589 \\
\hline $\begin{array}{l}\text { a sense that God is speaking to you (or } \\
\text { communicating in some way) }\end{array}$ & -0.005 & 0.682 \\
\hline $\begin{array}{l}\text { a sense that God is being "silent" or } \\
\text { unresponsive }\end{array}$ & -0.565 & 0.076 \\
\hline $\begin{array}{l}\text { questioning whether God really hears your } \\
\text { prayers }\end{array}$ & -0.771 & -0.080 \\
\hline $\begin{array}{l}\text { questioning whether God is interested in your } \\
\text { concerns }\end{array}$ & -0.621 & -0.093 \\
\hline $\begin{array}{l}\text { belief that God is not trying to communicate } \\
\text { with you }\end{array}$ & -0.783 & 0.017 \\
\hline
\end{tabular}

Note. Factor 1: Disengagement. Factor 2: Engagement. Factor scores are from an exploratory factor analysis with maximum likelihood extraction and direct oblimin rotation. Items in boldface were assigned to the factor represented in that column.

Next, we turned to Sample 2 to evaluate the factor structure once again, this time using a confirmatory factor analysis (CFA). We also used Sample 2 for our preliminary tests of validity.

\section{Sample 2: Method and Results}

\subsection{Method}

\subsubsection{Participants and Procedure}

See Section 2.1 for recruitment details. Table 1, right column, presents demographic data for participants in Sample 2.

\subsubsection{Measures}

Unless otherwise indicated, all measures and subscales in this section were scored by averaging across items. Table 5 presents the number of items, ranges, means, standard deviations, and alphas for all of these measures as well as the new measure of perceived divine engagement/disengagement in response to prayer.

Perceived divine engagement/disengagement in response to prayer. Section 2.3 describes the new measure. Tables 2 and 4 list the items.

Religious belief salience. Participants completed a four-item adaptation of the Religious Belief Salience Scale (Blaine and Crocker 1995), omitting one item that assumed belief in God. A sample item is, "My religious/spiritual beliefs lie behind my whole approach to life." Items were rated from 0 (does not apply; strongly disagree) to 10 (strongly agree) and were scored by averaging across items. An alpha of 0.97 was shown in prior research using this measure (Exline et al. 2014).

Current belief and doubt about God's existence. Participants used a scale from 0 (not at all) to 10 (totally) in response to these prompts: "To what extent do you believe that God exists?" and "Do you have doubts or questions about whether God exists?" These items have been used in prior studies (e.g., Exline et al. 2015). 
Table 5. Sample 2: Descriptive Statistics for Key Measures $(N=413)$.

\begin{tabular}{ccccc}
\hline & Number of Items & Range & $\boldsymbol{M}(\mathrm{SD})$ & $\boldsymbol{\alpha}$ \\
\hline Divine engagement & 4 & $1-5$ & $3.3(0.8)$ & 0.82 \\
\hline Divine disengagement & 4 & $1-5$ & $2.3(0.8)$ & 0.78 \\
\hline Religious belief salience & 4 & $0-10$ & $7.1(3.0)$ & 0.96 \\
\hline Belief in God's existence & 1 & $0-10$ & $9.0(1.9)$ & - \\
\hline Doubt about God's existence & 1 & $0-10$ & $3.4(3.6)$ & - \\
\hline Belief in divine intervention & 6 & $1-6$ & $4.6(1.1)$ & 0.84 \\
\hline & & & & \\
\hline God concept (God-10) & & & & \\
\hline Loving & 3 & $0-10$ & $9.3(1.4)$ & 0.91 \\
\hline Cruel & 3 & $0-10$ & $0.9(1.6)$ & 0.81 \\
\hline Distant & 4 & $0-10$ & $1.6(2.1)$ & 0.86 \\
\hline
\end{tabular}

\begin{tabular}{cllll}
\hline Attitudes toward God & & & & \\
\hline Positive attitudes & 5 & $0-10$ & $7.9(2.4)$ & 0.95 \\
\hline Anger/disappointment & 4 & $0-10$ & $1.4(2.1)$ & 0.93 \\
\hline Concern about God's disapproval & 3 & $0-10$ & $2.3(2.4)$ & 0.87 \\
\hline
\end{tabular}

\begin{tabular}{ccccc}
\hline $\begin{array}{c}\text { Spiritual Transformation } \\
\text { Inventory subscales }\end{array}$ & & & & \\
\hline Awareness & 5 & $1-5$ & $3.1(1.0)$ & 0.88 \\
\hline Gratitude to God & 5 & $1-5$ & $3.8(1.1)$ & 0.94 \\
\hline Secure attachment (to God) & 5 & $1-5$ & $3.6(1.0)$ & 0.86 \\
\hline Anxious attachment & 5 & $1-5$ & $1.9(0.8)$ & 0.86 \\
\hline Distant attachment & 5 & $1-5$ & $1.8(0.8)$ & 0.85 \\
\hline
\end{tabular}

\begin{tabular}{cllll}
\hline Styles of religious coping & & & & \\
\hline Collaborative & 6 & $1-5$ & $3.0(1.0)$ & 0.92 \\
\hline Deferring & 6 & $1-5$ & $2.9(0.9)$ & 0.87 \\
\hline Self-directing & 6 & $1-5$ & $2.6(0.9)$ & 0.90 \\
\hline
\end{tabular}

\begin{tabular}{ccccc}
$\begin{array}{c}\text { Religious/spiritual struggles } \\
\text { (RSS) }\end{array}$ & & & & \\
\hline Total score & 26 & $1-5$ & $2.0(0.7)$ & 0.94 \\
\hline Divine & 5 & $1-5$ & $1.6(0.8)$ & 0.89 \\
\hline Doubt & 4 & $1-5$ & $2.0(1.0)$ & 0.89 \\
\hline Ultimate Meaning & 4 & $1-5$ & $2.0(1.0)$ & 0.87 \\
\hline Interpersonal & 5 & $1-5$ & $1.8(0.8)$ & 0.83 \\
\hline Moral & 4 & $1-5$ & $2.6(1.0)$ & 0.84 \\
\hline Demonic & 4 & $1-5$ & $2.0(1.1)$ & 0.91 \\
\hline
\end{tabular}

Belief in divine intervention. Participants completed the six-item Belief in Divine Intervention Scale (BDIS; Degelman and Lynn 1995). Items are rated from 1 = strongly 
disagree to 6 = strongly agree, with two items reverse-scored. A sample item is, "God sometimes directly intervenes to heal individuals of diseases like cancer." An alpha of 0.91 was reported by Degelman and Lynn (1995).

God's qualities: cruel, distant, loving. Participants who endorsed some belief in God read the prompt, "Generally speaking, I imagine God as being ... " and completed the God-10 (Exline et al. 2015), which contains ten adjectives split between three subscales: Loving (loving, caring, forgiving), Cruel (cruel, unkind, rejecting), and Distant (distant, remote, unavailable, uninvolved). Items are rated from 0 (not at all) to 10 (extremely). Alphas reported in the 2015 article were as follows: Cruel: 0.90 to 0.91; Distant: 0.88 to 0.92; Loving: 0.94 to 0.96 .

God-related attitudes: positive attitudes, anger/disappointment, and concern about disapproval. Participants completed the Attitudes Toward God Scale-9 (ATGS-9; Wood et al. 2010), which has two subscales: Positive Attitudes (5 items, e.g., feel supported by God) and Anger/Disappointment (4 items, e.g., feel angry at God). Mixed with these items were three items on God's disapproval, which have been used in other articles (Exline et al. 2015, 2016): "believe that God sees you as a bad person," "fear that God will condemn you for your mistakes," and "believe that God disapproves of you." All items were rated from 0 (not at all) to 10 (extremely). Alphas reported in the original article (Wood et al. 2010) were 0.94 to 0.97 for Positive Attitudes and 0.80 to 0.93 for Anger/Disappointment. For God's disapproval, an alpha of 0.87 has been reported (Exline et al. 2015, 2016).

Perceived relationship with God: awareness, attachment, and gratitude to God. Participants completed several subscales of the Spiritual Transformation Inventory (Hall 2015), including Awareness of God (e.g., "I regularly sense God speaking to me personally"), Secure Connection to God (e.g., "I am comfortable seeking comfort from God when I am hurt or distressed"), Anxious Connection to God (e.g., "I feel like I have to work hard to be good so that God won't leave me"), Distant Connection to God (e.g., "I do not feel the need to depend on God"), and Gratitude to God (e.g., "I often feel thankful for what God has done in my life"). All items are rated from 1 (not at all true) to 5 (very true). Alphas reported by Hall (2015) were as follows: Awareness of God: 0.92; Secure Connection to God: 0.82; Anxious Connection to God: 0.84; Distant Connection to God: 0.85; Gratitude to God: 0.88.

Styles of religious coping. Participants completed a measure of three styles of religious coping (Pargament et al. 1988), which contains three subscales of six items each: Collaborative (e.g., "When it comes to deciding how to solve a problem, God and I work together as partners"), Deferring (e.g., "I do not think about difficult solutions to my problems because God provides them for me") and Self-Directing (e.g., "When I have difficulty, I decide what it means by myself without help from God"). Participants rated the frequency with which each item applied to them, using a scale from 1 (never) to 5 (always). Alphas reported in the original article (Pargament et al. 1988) were as follows: Collaborative: 0.94; Self-Directing: 0.94; Deferring: 0.91.

Religious and spiritual struggles. Participants completed the 26-item Religious and Spiritual Struggles (RSS) Scale (Exline et al. 2014), with the past several months used as the timeframe. The RSS has 6 subscales of four to five items each: Divine, Demonic, Interpersonal, Moral, Doubt, and Ultimate Meaning. All items are rated from 1 (not at all/does not apply) to 5 (a great deal). Alphas in the original article (Exline et al. 2014) were as follows: Divine: 0.89 to 0.93; Demonic: 0.90 to 0.93; Interpersonal: 0.82 to 0.85; Moral: 0.88; Ultimate Meaning: 0.87 to 0.89 ; Doubt: 0.89 to 0.90 .

\subsection{Analysis Plan}

After the basic item-level analyses on perceived divine engagement and disengagement (see Table 3), we first examined basic descriptive statistics for all study variables (Section 5.3.1). After this, we performed a confirmatory factor analysis (Section 5.3.2) to see whether the proposed divine engagement/disengagement items would show a similar structure to that produced by the EFA in Sample 1. After these basic analyses on the structure of the new measure, we conducted some initial tests of validity. We began with 
basic correlational analyses to provide initial tests of convergent and discriminant validity (Section 5.3.3), and we ran supplemental regressions (Section 5.3.4) to help distinguish between the predictive roles of divine engagement and disengagement and to control for the role of religious belief salience. We provided tests of incremental validity in a final set of regressions (Section 5.3.5).

\subsection{Results}

\subsubsection{Descriptive Statistics and Reliability}

Table 5 presents descriptive statistics (range, $M, S D, \alpha$ ) for all continuous variables. As in Sample 1, participants reported higher levels of divine engagement $(M=3.3, S D=0.8)$ than disengagement $(M=2.3, S D=0.8), t(412)=14.35, p<0.001$, Cohen's $d=1.17$, as expected. As in Sample 1, alpha reliabilities for divine engagement were acceptable, though not especially high ( $\alpha=0.82$ for divine engagement, $\alpha=0.78$ for divine disengagement). This moderate level of internal consistency may reflect, in part, the brevity of the subscales (four items each) as well as the breadth of content that each one covered: The subscales assessed an array of related but conceptually distinct responses related to God, including interest, listening, answering, giving guidance, and communication broadly defined.

On average, participants reported moderately high religious belief salience, high levels of belief in God with low to moderate levels of doubt, and moderate levels of belief in divine intervention. Their self-reported God concepts were overwhelmingly positive: On average, they saw God as very loving and reported high levels of positive attitudes toward God, although average scores on secure attachment to God, gratitude to God, awareness of God's presence, and belief in divine intervention were more moderate. Scores on the cruel and distant God concept subscales were low, as were reports of anger/disappointment toward God, concern about God's disapproval, and anxious and distant attachment to God. Scores on the collaborative, deferring and self-directing religious coping subscales were all in the moderate range. Overall levels of religious/spiritual struggle, including divine struggle, were modest.

\subsubsection{Confirmatory Factor Analysis (CFA)}

Building on the exploratory factor analysis (EFA) from Sample 1, we performed a confirmatory factor analysis (CFA) using AMOS version 26. We conducted a simple structure model allowing each item to load on one factor only (See Figure 1). The model showed an acceptable fit to the data, $\chi^{2}(19, N=413)=65.517, p=0.000$, CFI $=0.958$, RMSEA $=0.077$, SRMR $=0.052$, PCLOSE $=0.014$. Note that significant chi-squares are common in large samples (Bentler and Bonett 1980). As noted in the correlation table presented earlier (Table 3), a few items did correlate moderately (and negatively) with items assigned to the other subscale, though these links made sense conceptually. Although it is likely that we could have improved the fit by allowing some items to cross-load on the other factor (perhaps especially the "Answer" item, which had a cross-loading of 0.267 in the EFA), we did not take this step because our main aim here was simply to evaluate whether the two-subscale model was viable. We anticipated that most researchers would prefer to score the scale by simply assigning items to subscales rather than computing factor scores.

\subsubsection{Convergent and Discriminant Validity Tests: Initial Correlations}

We began our validity testing by examining bivariate correlations between classically computed subscales for divine engagement, divine disengagement, and our other key variables. For the analyses that follow, we organized the validation variables by focusing on those with positive valence first, followed by those with negative valence or an implication of distance from God. 


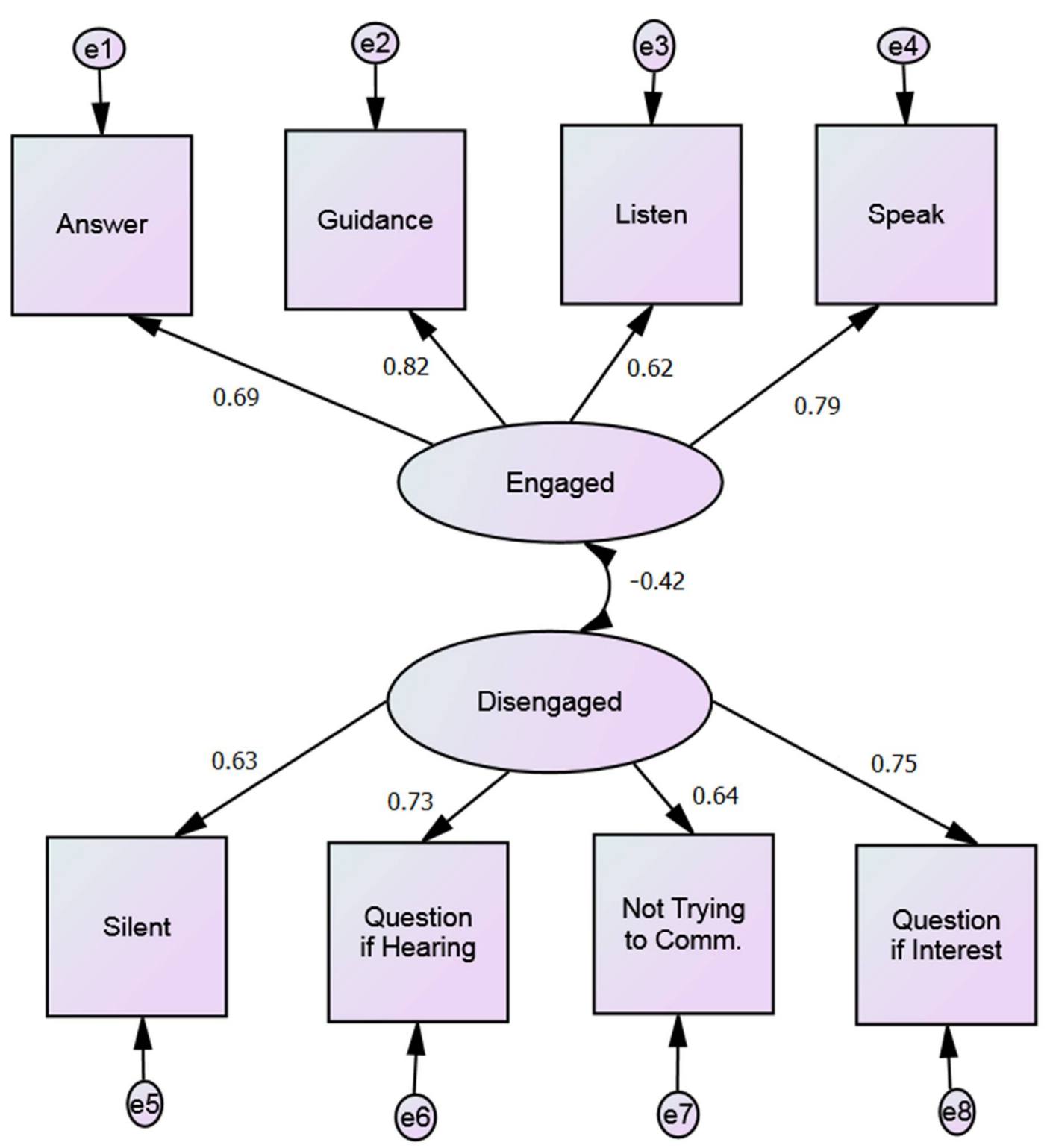

Figure 1. Confirmatory Factor Analysis on Divine Engagement and Disengagement Items (Sample 2). $\chi^{2}(19$, $N=413)=65.517, p=0.000, \mathrm{CFI}=0.958, \mathrm{RMSEA}=0.077, \mathrm{SRMR}=0.052$, and PCLOSE $=0.014$.

Initial Tests of Convergent Validity

Using recent effect size guidelines by Funder and Ozer (2019) and Gignac and Szodorai (2016) that define small effects as 0.10 , moderate as 0.20 , and large as 0.30 , we expected the divine engagement subscale to show strong positive correlations with religious belief salience, belief in God's existence, and positive-valence variables focused on God: loving God images, positive attitudes toward God, awareness of God's presence, secure attachment to God, gratitude to God, and collaborative and deferring religious coping styles. These hypotheses were strongly supported, as the left column of Table 6 shows. (As a side note, we acknowledge that the deferring style, in which people expect God to solve their problems for them without activity on their part (Pargament et al. 1998), is usually not seen as being as adaptive as the collaborative style, in which people work together with God; however, since the deferring coping style does imply a strong sense of trust in God, we expected it to show a clear positive association with a sense of divine engagement.) 
Table 6. Correlations of Key Variables with Divine Engagement and Disengagement (Sample 2; $N=413)$.

\begin{tabular}{ccc}
\hline & Divine Engagement & Divine Disengagement \\
\hline Divine engagement & 1.0 & $-0.36^{* *}$ \\
\hline Divine disengagement & $-0.36^{* *}$ & 1.0 \\
\hline Positive-valence God variables & & \\
\hline Religious belief salience & $0.60^{* *}$ & $-0.29^{* *}$ \\
\hline Belief in God's existence & $0.50^{* *}$ & $-0.31^{* *}$ \\
\hline Loving God concept (God-10) & $0.44^{* *}$ & $-0.32^{* *}$ \\
\hline Positive attitudes toward God & $-0.34^{* *}$ \\
\hline (ATGS-9) & $0.54^{* *}$ & $-0.32^{* *}$ \\
\hline Cocure attachment (to God) (STI) & $0.61^{* *}$ & $-0.24^{* *}$ \\
\hline Deferring religious coping & $0.50^{* *}$ & $-0.15^{* *}$ \\
\hline Awareness of God's presence (STI) & $0.49^{* *}$ & $-0.32^{* *}$ \\
\hline Belief in divine intervention (BDIS) & $0.64^{* *}$ & $-0.37^{* *}$ \\
\hline Gratitude to God (STI) & $0.55^{* *}$ & $-0.32^{* *}$ \\
\hline & $0.61^{* *}$ & \\
\hline
\end{tabular}

\begin{tabular}{ccl}
\hline $\begin{array}{c}\text { Negative-valence and } \\
\text { distance-related God variables }\end{array}$ & \\
\hline Doubt about God's existence & $-0.35^{* *}$ & $0.39^{* *}$ \\
\hline Cruel God concept (God-10) & $-0.38^{* *}$ & $0.39^{* *}$ \\
\hline Distant God concept (God-10) & $-0.48^{* *}$ & $0.51^{* *}$ \\
\hline Anger/disappointment (ATGS-9) & $-0.28^{* *}$ & $0.44^{* *}$ \\
\hline Concern about God's disapproval & $-0.23^{* *}$ & $0.39^{* *}$ \\
\hline Anxious attachment (STI) & $-0.19^{* *}$ & $0.47^{* *}$ \\
\hline Distant attachment (STI) & $-0.34^{* *}$ & $0.44^{* *}$ \\
\hline Self-directing religious coping & $-0.34^{* *}$ & $0.38^{* *}$ \\
\hline
\end{tabular}

\begin{tabular}{|c|c|c|}
\hline $\begin{array}{l}\text { Religious/spiritual strug } \\
\text { (RSS) }\end{array}$ & & \\
\hline Total RSS & -0.07 & 0.42 ** \\
\hline Divine & $-0.16^{* *}$ & $0.48^{* *}$ \\
\hline Doubt & $-0.21^{* *}$ & $0.47 * *$ \\
\hline Ultimate Meaning & $-0.17^{* *}$ & $0.45^{* *}$ \\
\hline Interpersonal & -0.04 & 0.30 ** \\
\hline Moral & 0.07 & $0.13^{* *}$ \\
\hline Demonic & $0.18^{* *}$ & 0.10 * \\
\hline
\end{tabular}

In a parallel fashion, we expected divine disengagement to show strong positive associations with negative-valence variables focused on God (cruel God image; divine struggle; anger/disappointment toward God; concern about God's disapproval; anxious attachment to God) and those suggesting a sense of distance in the relationship (i.e., doubt 
about God's existence; distant God concept; distant attachment; self-directing religious coping). These hypotheses were also supported (Table 6, right column).

Correlations between Items Assigned to the Engagement and Disengagement Subscales

Due to the expected negative association between divine engagement and disengagement, we expected divine engagement to show moderate negative links with the negative-valence and distance-related God items. In a parallel fashion, we expected divine disengagement to show moderate negative links with the positive-valence God items. These predictions were partially supported, as Table 6 shows. Although the expected associations were present, many of them were large rather than moderate in magnitude. We will elaborate more on this point below when we describe the regression results.

\section{Links with Spiritual Struggle: Convergent and Discriminant Validity}

We expected divine disengagement to show strong positive associations with divine struggle and spiritual struggle in general, along with doubt-related struggles and ultimate meaning struggles: We reasoned that people who questioned that God was hearing them would also experience other sources of doubt about their faith, and we also expected that a lack of perceived direction from God would be associated with a perceived lack of meaning or purpose in life. The expected associations did emerge, as the bottom section of Table 6 (right column) shows. In terms of discriminant validity, we expected divine disengagement to show only small associations with demonic, moral and interpersonal struggles, as we did not see these subscales as directly relevant to perceptions of God listening or speaking. These hypotheses were supported, except that the association with interpersonal struggle was large rather than small. Perhaps this stronger-than-expected link emerged because divine struggles and interpersonal struggles around religion both involve relational dynamics.

We expected divine engagement to show small to moderate negative associations with the divine, doubt, and ultimate meaning subscales, based on the negative correlations between divine engagement and disengagement. This hypothesis was supported (Table 6, bottom section, left column). We did not expect divine engagement to show significant negative relationships with the demonic, moral, or interpersonal subscales; on the contrary, we anticipated that divine engagement would show a small to moderate positive relationship with moral and demonic struggles, given that these subscales tend to correlate positively with religiousness (Exline et al. 2014; Stauner et al. 2016). We did not expect a significant correlation between divine engagement and interpersonal struggle. Table 6 (bottom section, left column) shows partial support for these predictions. As expected, divine engagement showed small to moderate negative associations with divine, ultimate meaning, and doubt struggles, a small positive association with demonic struggle, and nonsignificant associations with interpersonal struggles. We had expected a positive association with moral struggle, given its overlap with religiousness, but this hypothesis was not supported in the correlational analyses (This relationship did emerge in the regression analyses that we will review next, however).

\subsubsection{Supplemental Regressions}

Clarifying the Predictive Roles of Divine Engagement vs. Disengagement

Given the strong negative correlation between divine engagement and disengagement $(r=-0.36, p<0.01)$, along with the fact that divine engagement and disengagement both showed strong correlations with the negative-valence and distance-oriented variables (Table 6, middle section), we supplemented the correlational results from Table 6 with a set of simultaneous regressions (Table 7) in which we entered divine engagement and disengagement as predictors of the same variables from the correlation table. The primary aim was to see whether the overlap between divine engagement and disengagement would largely account for the negative associations between divine engagement, disengagement, and their opposite-valence constructs (e.g., divine engagement with cruel and distant God 
images; divine disengagement with loving God images and secure attachment to God; see Table 6). We expected this to be the case.

Table 7. Simultaneous Regressions Predicting Key Variables from Divine Engagement and Disengagement.

\begin{tabular}{|c|c|c|c|}
\hline Criterion & $\begin{array}{c}\text { Divine } \\
\text { Engagement } \\
\beta\end{array}$ & $\begin{array}{c}\text { Divine } \\
\text { Disengagement } \\
\text { B }\end{array}$ & $R^{2}$ \\
\hline \multicolumn{4}{|l|}{ Positive-valence variables } \\
\hline Religious belief salience & $0.57^{* *}$ & $-0.10 *$ & $0.37^{* *}$ \\
\hline Belief in God's existence & $0.44^{* *}$ & $-0.15^{* *}$ & $0.27^{* *}$ \\
\hline Loving God concept (God-10) & $0.38^{* *}$ & $-0.19^{* *}$ & $0.23 * *$ \\
\hline $\begin{array}{l}\text { Positive attitudes toward God } \\
\text { (ATGS-9) }\end{array}$ & $0.48^{* *}$ & $-0.18^{* *}$ & $0.32 * *$ \\
\hline Secure attachment (to God) (STI) & $0.45^{* *}$ & $-0.22 * *$ & $0.32 * *$ \\
\hline Collaborative religious coping & $0.48^{* *}$ & -0.07 & $0.26^{* *}$ \\
\hline Deferring religious coping & $0.50 * *$ & 0.03 & $0.24^{* *}$ \\
\hline Awareness of God's presence (STI) & $0.60 * *$ & $-0.11^{* *}$ & $0.42^{* *}$ \\
\hline Belief in divine intervention (BDIS) & $0.48^{* *}$ & $-0.20 * *$ & 0.34 ** \\
\hline Gratitude to God (STI) & $0.57^{* *}$ & $-0.12 * *$ & $0.38^{* *}$ \\
\hline \multicolumn{4}{|l|}{$\begin{array}{l}\text { Negative-valence and distant God } \\
\text { variables }\end{array}$} \\
\hline Doubt about God's existence & $-0.24^{* *}$ & $0.31^{* *}$ & $0.20 * *$ \\
\hline Cruel God concept (God-10) & $-0.28^{* *}$ & $0.29 * *$ & $0.22 * *$ \\
\hline Distant God concept (God-10) & $-0.34^{* *}$ & $0.39 * *$ & $0.36^{* *}$ \\
\hline Anger/disappointment (ATGS-9) & $-0.15^{* *}$ & $0.39 * *$ & $0.21^{* *}$ \\
\hline Concern about God's disapproval & $-0.11 *$ & $0.36^{* *}$ & $0.16^{* *}$ \\
\hline Anxious attachment (STI) & -0.03 & $0.46^{* *}$ & $0.21 * *$ \\
\hline Distant attachment (STI) & $-0.21^{* *}$ & $0.37 * *$ & $0.23^{* *}$ \\
\hline Self-directing religious coping & $-0.24^{* *}$ & $0.30 * *$ & $0.20 * *$ \\
\hline \multicolumn{4}{|l|}{ Religious/spiritual struggles (RSS) } \\
\hline Total RSS & $0.10 *$ & $0.45 * *$ & $0.18^{* *}$ \\
\hline Divine & 0.02 & $0.49^{* *}$ & $0.24^{* *}$ \\
\hline Doubt & -0.05 & $0.45^{* *}$ & $0.22 * *$ \\
\hline Ultimate Meaning & -0.01 & $0.44^{* *}$ & $0.20 * *$ \\
\hline Interpersonal & 0.08 & $0.32 * *$ & $0.09^{* *}$ \\
\hline Moral & $0.14^{* *}$ & $0.18 * *$ & $0.03^{* *}$ \\
\hline Demonic & $0.25 * *$ & $0.20 * *$ & $0.07^{* *}$ \\
\hline
\end{tabular}

As the top part of Table 7 clarifies, perceptions of divine engagement predicted large amounts of unique variance in the positive-valence variables involving God (with betas ranging from 0.38 for a loving God concept to 0.60 for awareness of God's presence). Divine disengagement did not predict unique variance in collaborative or deferring religious coping, but it did predict small to moderate amounts of unique variance in the other constructs (betas ranging from -0.10 for religious belief salience to -0.22 for secure attachment to God).

As the middle section of Table 7 shows, divine disengagement was a moderate to strong predictor of unique variance in the other negative or distance-oriented variables (betas ranging from 0.29 for cruel God concept to 0.46 for anxious attachment), as expected. But here, the role of divine engagement showed substantial variability, with betas ranging from -0.03 for anxious attachment to -0.34 for distant God concept. Of the five beta weights that exceeded 0.20 for divine engagement, four focused on constructs suggesting a less distant relationship with God: Higher scores on divine engagement were associated with less doubt about God's existence (moderate effect), a less distant God concept (large effect), less distant attachment (moderate effect), and less self-directing religious coping (moderate effect). In addition, divine engagement was also associated with a less cruel image of God (moderate effect). 
When predicting religious/spiritual struggle using the RSS total score and the RSS subscales, the distinction between divine disengagement and engagement emerged more consistently. Divine disengagement explained unique variance in all of the religious/spiritual struggle variables, with associations in the strong range ( $\beta$ s from 0.44 to 0.49 ) for total struggle, divine struggle, doubt struggle, and ultimate meaning struggle, as expected. Divine disengagement also predicted small to large amounts of unique variance in the remaining struggles ( $\beta$ s: 0.18 for moral struggle, 0.20 for demonic, 0.32 for interpersonal). The results for divine disengagement were generally in line with expectations, although the beta weight for interpersonal struggle was higher than expected (as had been reflected in the correlations in Table 6).

As expected, divine engagement did not predict unique variance in divine, doubt, interpersonal, or ultimate meaning struggles when divine disengagement was controlled; however, divine engagement did predict unique variance in moral and demonic struggles, in the direction of greater struggles. We performed supplemental analyses next to assess whether religiousness accounted for these associations.

\section{Supplemental Regression Controlling for Religious Belief Salience}

As Table 7 shows, divine engagement predicted small to moderate amounts of unique variance in moral, demonic, and total struggle-but the associations were in the direction of greater struggle, as expected. It was important to do supplemental analyses here to control for the role of religious belief salience, as moral and demonic struggles are the ones that tend to show consistent positive associations with religiousness, sometimes leading to misleading associations (Exline et al. 2014; Stauner et al. 2016). Although our main interest here was in moral and demonic struggles, we ran these analyses across all RSS subscales for thoroughness. Table 8 clarifies that in each case, when we added religious belief salience to the equation, the beta weight for divine engagement was reduced to nonsignificance, while the betas for religious belief salience and disengagement were significant (and moderate).

Table 8. Simultaneous Regressions Predicting Religious/Spiritual Struggles from Divine Engagement, Disengagement, and Religious Belief Salience.

\begin{tabular}{lcccc}
\hline Criterion & $\begin{array}{c}\text { Divine } \\
\text { Engagement } \\
\boldsymbol{\beta}\end{array}$ & $\begin{array}{c}\text { Divine } \\
\text { Disengagement } \\
\mathbf{B}\end{array}$ & $\begin{array}{c}\text { Religious Belief } \\
\text { Salience } \\
\text { B }\end{array}$ & $\boldsymbol{R}^{\mathbf{2}}$ \\
\hline Total RSS & 0.01 & $0.46^{* *}$ & $0.16^{* *}$ & $0.19^{* *}$ \\
Divine & -0.02 & $0.49^{* *}$ & 0.06 & $0.23^{* *}$ \\
Doubt & -0.08 & $0.45^{* *}$ & 0.05 & $0.22^{* *}$ \\
Ultimate & 0.05 & $0.43^{* *}$ & $-0.11+$ & $0.21^{* *}$ \\
Meaning & -0.01 & $0.33^{* *}$ & $0.15^{*}$ & $0.10^{* *}$ \\
Interpersonal & -0.01 & $0.20^{* *}$ & $0.27^{* *}$ & $0.08^{* *}$ \\
Moral & 0.09 & $0.22^{* *}$ & $0.29^{* *}$ & $0.12^{* *}$ \\
Demonic & & & &
\end{tabular}

5.3.5. Tests of Incremental Validity: Do Divine Engagement and Disengagement Provide Additional Explanatory Power?

In trying to understand the broad picture of a person's perceived relationship with God (e.g., religious coping strategies; divine struggle; attachment to God), might perceptions of divine engagement and disengagement have any distinct predictive power, even when we control for other specific, known predictors of these broad relational measures? To address these questions of incremental validity, we performed a rigorous set of tests: Specifically, we examined whether perceptions of divine engagement and disengagement would predict any unique variance in several variables related to perceived relationships with God (positive and negative), even when controlling for several other basic Godoriented variables (religious belief salience, belief that God exists, seeing God as loving, positive attitudes toward God) that could be expected to predict considerable variance in 
the relationally-focused God variables. For these analyses, we separated positive-valence God variables (Table 9) and negative-valence and distant God variables (Table 10) rather than mixing them. Our aim was to see whether perceived engagement would predict additional variance in positive-valence relational variables focused on God even when controlling for several distal, general positive-valence variables (religiousness, belief in God, God concept, attitudes toward God). We also performed parallel analyses for the distance-focused and negative-valence God variables.

Table 9. Predicting Positive God-Related Variables from Divine Engagement and Other Indicators of a Positive Relationship with God: Simultaneous Regressions.

\begin{tabular}{|c|c|c|c|c|c|c|}
\hline $\begin{array}{l}\text { Criterion } \\
\text { Variables } \\
\text { Predictors } \\
\text { (with } \beta \text { s) }\end{array}$ & $\begin{array}{c}\text { Secure } \\
\text { Attachment to } \\
\text { God }\end{array}$ & $\begin{array}{c}\text { Awareness of } \\
\text { God's Presence }\end{array}$ & $\begin{array}{l}\text { Collaborative } \\
\text { Religious } \\
\text { Coping }\end{array}$ & $\begin{array}{l}\text { Deferring } \\
\text { Religious } \\
\text { Coping }\end{array}$ & $\begin{array}{c}\text { Belief in } \\
\text { Divine } \\
\text { Intervention }\end{array}$ & $\begin{array}{c}\text { Gratitude } \\
\text { to } \\
\text { God }\end{array}$ \\
\hline Divine engagement & $0.13^{* *}$ & $0.37 * *$ & $0.27 * *$ & $0.25^{* *}$ & $0.18 * *$ & $0.22 * *$ \\
\hline $\begin{array}{l}\text { Religious belief } \\
\text { salience }\end{array}$ & $0.24^{* *}$ & $0.22 * *$ & $0.12 *$ & $0.24^{* *}$ & $0.26^{* *}$ & $0.21 * *$ \\
\hline $\begin{array}{l}\text { Belief in God's } \\
\text { existence }\end{array}$ & 0.06 & $0.11 *$ & $0.11+$ & $0.11+$ & $0.16^{* *}$ & $0.09+$ \\
\hline $\begin{array}{l}\text { Loving God } \\
\text { concept }\end{array}$ & -0.01 & -0.06 & -0.04 & $-0.10+$ & $0.16^{* *}$ & -0.04 \\
\hline $\begin{array}{c}\text { Positive attitudes } \\
\text { toward God }\end{array}$ & $0.44^{* *}$ & $0.22 * *$ & $0.24^{* *}$ & $0.17^{* *}$ & $0.10+$ & $0.45^{* *}$ \\
\hline$R^{2}$ & $0.55^{* *}$ & $0.53 * *$ & $0.35^{* *}$ & $0.35 * *$ & $0.48^{* *}$ & $0.63 * *$ \\
\hline
\end{tabular}

Except for bottom row, all numbers are $\beta \mathrm{s} .+p<0.10 ;{ }^{*} p<0.05 ;{ }^{* *} p<0.01$.

Table 10. Predicting Divine Struggle and Distant Relationships with God from Divine Disengagement and other Indicators of Divine Struggle: Simultaneous Regressions.

\begin{tabular}{|c|c|c|c|c|c|}
\hline $\begin{array}{l}\text { Criterion Variables } \\
\text { Predictors (with } \beta s \text { ) }\end{array}$ & $\begin{array}{l}\text { Spiritual Struggle } \\
\text { (Total RSS) }\end{array}$ & $\begin{array}{l}\text { Divine } \\
\text { Struggle }\end{array}$ & $\begin{array}{c}\text { Anxious } \\
\text { Attachment to } \\
\text { God }\end{array}$ & $\begin{array}{c}\text { Distant } \\
\text { Attachment to } \\
\text { God }\end{array}$ & $\begin{array}{l}\text { Self-Directing } \\
\text { Religious Coping }\end{array}$ \\
\hline Divine disengagement & $0.25^{* *}$ & $0.28^{* *}$ & $0.16^{* *}$ & $0.11 *$ & $0.19 * *$ \\
\hline $\begin{array}{l}\text { Doubt re: God's } \\
\text { existence }\end{array}$ & -0.05 & -0.05 & 0.02 & 0.09 * & $0.18^{* *}$ \\
\hline Cruel God concept & 0.03 & -0.02 & $-0.10 *$ & -0.01 & -0.04 \\
\hline Distant God concept & 0.02 & 0.06 & 0.05 & 0.08 & 0.06 \\
\hline Anger/disappointment & $0.20 * *$ & $0.43^{* *}$ & $0.36 * *$ & $0.42 * *$ & 0.10 \\
\hline $\begin{array}{c}\text { Concern about God's } \\
\text { disapproval }\end{array}$ & $0.23^{* *}$ & 0.07 & $0.41^{* *}$ & $0.20 * *$ & $0.16^{*}$ \\
\hline$R^{2}$ & $0.33^{* *}$ & $0.44^{* *}$ & $0.62 * *$ & $0.52 * *$ & $0.24^{* *}$ \\
\hline
\end{tabular}

Except for bottom row, all numbers are $\beta s .{ }^{*} p<0.05 ;{ }^{* *} p<0.01$.

Note that these were extremely stringent tests, given that we were controlling for measures of belief in God, God concept, attitudes toward God, and (in the case of positive experiences with God), religious belief salience. If perceptions of divine engagement and disengagement did predict unique variance with so many relevant factors controlled, this would strongly suggest that they are distinct constructs that may warrant separate examination and attention. Given that we were controlling so many other closely related variables, we expected divine engagement and disengagement to predict a modest amount of unique variance ( $\beta$ s between 0.10 and 0.20 ) in each case. 
In all cases, regressions did suggest that divine engagement and disengagement had distinct predictive power. As Table 9 (top row) shows, even when we controlled for the other specific, positive-valence variables involving God (religious belief salience, belief in God's existence, a loving God concept, and positive attitudes toward God), perceptions of divine engagement still predicted unique variance in all of the indicators of a positive, trusting, engaged bond with God: secure attachment, awareness of God's presence, collaborative and deferring religious coping, belief in divine intervention, and gratitude to God. Four of these six associations were stronger than expected, as we had anticipated $\beta \mathrm{s}$ of 0.20 or less.

Next we performed similar analyses focused on divine disengagement. As Table 10 (top row) shows, even when we controlled for other negative-valence God variables (doubt about God's existence, cruel and distant God concepts, anger/disappointment, and concern about God's disapproval), a sense of divine disengagement still predicted unique variance (small to moderate effect sizes) in all of the indicators that suggested strain or distance in a person's perceived bond with God: spiritual struggle, divine struggle, anxious and distant attachment, and self-directing religious coping. As with divine engagement, several of these coefficients (in this case, $\beta s$ for Total RSS and divine struggle) exceeded 0.20 and were thus slightly higher than expected.

\section{Discussion}

When people pray, they are reaching out and trying to communicate with God. Further, as in human relationships, people do seem to have different views about God's level of engagement in these conversations. Some people envision God listening carefully and actively responding to their prayers, while others imagine God being more disengaged: perhaps disinterested in their prayers or not really hearing them, or being silent in response. In this article, we provided initial evidence of reliability and validity (convergent, discriminant, and incremental validity) for a brief measure of perceptions of divine engagement and disengagement in response to prayer.

\subsection{Factor Structure and Reliability for the Two Proposed Subscales}

In two samples of undergraduates using exploratory and confirmatory factor analysis, we found support for a two-factor solution capturing the proposed facets of divine engagement and disengagement, each measured by four items. The divine engagement items captured a sense that God was listening and responding to prayers, whereas the disengagement items focused on questions about whether God was actually interested or hearing one's prayers, along with a sense of God being silent or not trying to communicate.

The fact that each subscale, using only four items, tapped a range of communicationrelated concepts may help to explain why internal consistency was not especially high, though still acceptable (Engagement: $\alpha \mathrm{s}=0.80$ (Sample 1) and 0.82 (Sample 2); Disengagement: $\alpha \mathrm{s}=0.79$ (Sample 1) and 0.78 (Sample 2)). However, these moderate alphas also suggest that the four items on each subscale are not highly redundant. Further, the measures were sufficiently reliable to show clear associations with related constructs, as we will detail below.

\subsection{Item-Level Comparisons}

In both samples, scale-level and item-level analyses showed that participants reported greater perceived divine engagement than disengagement, as expected. In terms of divine engagement, the most highly endorsed response was a sense that God was listening to the prayer, followed by a sense of God giving guidance, with the items on God answering and speaking receiving lower endorsement. In terms of divine disengagement, participants were most likely to report a sense that God was being silent or unresponsive in response to their prayers. They were less likely to report questioning whether God heard their prayers or was interested in them. Further, of all eight items, the one that received the lowest endorsement was the item suggesting that God was not trying to communicate. One way 
to frame these results might be to emphasize the difficulty of endorsing each item. For the engagement subscale, it was relatively easy for participants to endorse the item about God listening, whereas it was somewhat harder to endorse the more active forms of engagement, such as speaking. In terms of the disengagement items, it was moderately difficult for participants to endorse the item suggesting that God was being silent or unresponsive, whereas it appeared quite difficult to claim that God was not trying to communicate at all.

\subsection{Convergent and Discriminant Validity}

As expected, divine engagement and disengagement showed moderate negative correlations, clarifying that they are distinct, though related constructs. Sample 2 correlations (Table 6) and regressions (Table 7) provided initial evidence of convergent and discriminant validity for the new measure. In general, these analyses showed that divine engagement and disengagement correlated in expected directions with measures of God-related attitudes and beliefs as well as spiritual struggles.

\subsubsection{Divine Engagement}

As expected, perceptions of divine engagement in response to prayer showed strong positive links with religious belief salience, belief in God, and other variables suggesting positive attitudes toward God: loving God concepts, seeing God as active in the world, awareness of God's presence, secure attachment to God, gratitude to God, and seeing oneself as being in a collaborative or deferring relationship with God.

Perceptions of divine engagement were also associated with lower levels of divine struggle and distance in one's perceived relationship with God, as expected. Not surprisingly, the most clear, consistent, and robust links were shown with variables that emphasized a sense of distance in the relationship: To the extent that participants saw God as responsive to their prayers, they reported less doubt about God's existence, a less distant God concept, less distant attachment to God, and lower levels of self-directing religious coping. They also saw God as substantially less cruel.

In terms of discriminant validity, perceptions of divine engagement showed weak, sometimes nonsignificant links with most indicators of spiritual struggle, as predicted. Further, positive associations with demonic and moral struggles were accounted for by religiousness, as expected (Table 8 ).

\subsubsection{Divine Disengagement}

Divine disengagement showed consistent, strong positive correlations with other indicators of divine struggle: not only the Divine subscale of the RSS but also doubt about God's existence, cruel and distant God concepts, anger/disappointment toward God, concern about God's disapproval, and anxious and distant attachment to God. Divine disengagement also showed strong positive links with spiritual struggle in general and with divine, doubt, and ultimate meaning struggles, as expected. In terms of discriminant validity, moral and demonic struggles showed only small associations with divine disengagement, as expected; however, the correlation with interpersonal struggle was higher than anticipated. Finally, divine disengagement showed significant (small to large) negative associations with the positive God-related variables, which were attenuated to some degree when the overlap between divine disengagement and engagement was controlled (Table 7).

\subsection{Incremental Validity}

In our view, some of the most important findings from this project relate to evidence of incremental validity for both the divine engagement and disengagement concepts. We will briefly review these findings next.

First, in a set of simultaneous regressions (Table 9), we examined the question of whether perceptions of divine engagement in response to prayer would predict unique variance in six different indicators of a positive relationship with God: secure attachment, awareness of God's presence, collaborative and deferring religious coping, belief in divine 
intervention, and gratitude to God. This was an extremely rigorous test, given that we controlled for several other foundational, positive-valence variables focusing on God: religious belief salience, belief in God, a loving God concept, and positive attitudes toward God. Across all six indicators of a positive relationship with God, a sense of divine engagement in response to prayer predicted unique variance above and beyond these closely related control variables, and four of these six associations were stronger than we had expected. Although not conclusive, these findings are consistent with the idea that a perception that God is listening and responding to prayers may be an important part of perceiving a secure, engaged, positive relationship with God.

In a parallel fashion, we used another set of simultaneous regressions (Table 10) to evaluate whether perceptions of divine disengagement would predict unique variance in spiritual struggle (Total RSS) as well as four different indicators of a troubled or distant relationship with God: divine struggle, anxious attachment, distant attachment, and selfdirecting religious coping. Here we controlled for several other indicators of divine struggle: doubt about God's existence, cruel and distant God concepts, anger/disappointment toward God, and concern about God's disapproval. In each case, divine disengagement explained small to moderate amounts of unique variance above and beyond these other variables relevant to divine struggle. In other words, the divine disengagement items seem to be tapping something that is partly distinct from doubts about God's existence as well as the divine struggles of anger/disappointment toward God, fear of God's disapproval or punishment, and feeling unloved or abandoned by God (which are well tapped in existing measures of divine struggle and insecure attachment to God). Taken together, these findings suggest that perceptions of divine disengagement may be an important, but overlooked, facet of divine struggle.

\subsection{Limitations and Future Directions}

Participants in this study were undergraduates from the United States. The sample was largely young, White and Christian. As such, we cannot draw any conclusions about generalizability to other cultures, age groups, or religious groups. It is also possible that beliefs about God within a culture might shift over time. Our data here were from 2013 and 2014 and thus represent only a small snapshot of college students at that time.

Our data were cross-sectional and correlational. Although we can point out connections between variables, there is no guarantee that perceptions of God's engagement or disengagement were affecting people's perceived relationships with God. It is perfectly reasonable to expect an opposite causal direction, in which a perception of a secure or insecure bond with God could color people's perceptions of divine engagement and disengagement. Third-variable explanations are also possible, perhaps related to factors such as emotional stability or a general tendency to think about God in a relational way. It is also possible that events happening in a person's life-whether positive or negative-could affect perceptions about whether God is listening and responding. In future work, it would be valuable to explore whether perceptions of divine engagement and disengagement in response to prayer might change in response to life events. It would also be interesting to consider whether a sense of divine engagement could have potential downsides, such as the possibility of engaging in spiritual bypass (Fox et al. 2017, 2020), in which people focus on spiritual topics as a way of sidestepping psychological challenges.

The scales on perceptions of divine engagement and disengagement were developed for this project, based on creation of a face-valid set of items. Although the measure has the advantage of being brief and covering constructs related to listening and responding, showed some tradeoff in terms of internal consistency (alphas from 0.78 to 0.82). Researchers who want to look more closely at the different facets of divine engagement and disengagement may want to develop more in-depth sets of items that can reliably assess these different facets. 


\subsection{Conclusions}

In human relationships, seeing another person as attentive and responsive is an important predictor of satisfaction and secure attachment. Is this true of perceived relationships with God as well? Does it matter to people whether they think that God is listening and responding when they pray? Our findings suggest that the answer may be yes, although we of course need to be cautious about drawing causal inferences from cross-sectional data.

In this article, we provided initial validation of a new, eight-item measure designed to assess these perceptions of divine engagement and disengagement in response to prayer. Importantly, the new subscales on divine engagement and disengagement both showed evidence not only of convergent and discriminant validity but also incremental validity: Divine engagement and disengagement each explained unique variance in other relationally-oriented variables focused on God (e.g., attachment to God; religious coping; divine struggles), even when controlling for other related God-focused constructs. We conclude that questions about whether God is actually listening and responding to prayers represent an important part of how people perceive their relationships with the divine.

We believe that these findings, though preliminary and awaiting replication, have potential clinical relevance. For example, doubts about whether God is actually interested, listening, or responsive to prayer might be valuable to assess as potential precursors to spiritual struggle or religious disengagement. On the other hand, if seeing God as attentive and responsive to prayers is indeed an important predictor of a positive, secure attachment bond with God, then perhaps greater attunement to ideas around God's listening and responsiveness could serve as important building blocks toward a sense of greater closeness, safety, and engagement in that perceived relationship. Spiritual direction might play a valuable role here for some individuals.

Author Contributions: Conceptualization, J.J.E. and V.A.H.; Data curation, J.J.E., K.I.P. and T.W.H.; Formal analysis, J.J.E.; Funding acquisition, J.J.E. and K.I.P.; Investigation, J.J.E.; Methodology, J.J.E. and J.A.W.; Project administration, J.J.E., K.I.P. and T.W.H.; Writing-original draft, J.J.E.; Writingreview \& editing, J.J.E., J.A.W., V.A.H., K.I.P. and T.W.H. All authors have read and agreed to the published version of the manuscript.

Funding: We are grateful for funding support from the John Templeton Foundation, Grants 36094 and 59916.

Institutional Review Board Statement: This project was approved by the Institutional Review Boards at Case Western Reserve University (2012-298), Bowling Green State University (381301-2), and Biola University (F12-019).

Informed Consent Statement: Informed consent was obtained from all participants involved in this study.

Data Availability Statement: Data from this project are not publicly available at this time, but the larger datasets on which this study is based will be shared within the next several years.

Conflicts of Interest: The authors declare no conflict of interest.

\section{References}

Beck, Richard, and Angie McDonald. 2004. Attachment to God: The Attachment to God Inventory, tests of working model correspondence, and an exploration of faith group differences. Journal of Psychology and Theology 32: 92-103. [CrossRef]

Bentler, Peter M., and Douglas G. Bonett. 1980. Significance tests and goodness of fit in the analysis of covariance structures. Psychological Bulletin 88: 588-606. [CrossRef]

Blaine, Bruce, and Jennifer Crocker. 1995. Religiousness, race, and psychological well-being: Exploring social psychological mediators. Personality and Social Psychology Bulletin 21: 1031-41. [CrossRef]

Büssing, Arndt, Andreas Günther, Klaus Baumann, Eckhard Frick, and Christoph Jacobs. 2013. Spiritual dryness as a measure of a specific spiritual crisis in Catholic priests: Associations with symptoms of burnout and distress. Evidence-Based Complementary and Alternative Medicine 2013: 246797. [CrossRef] 
Büssing, Arndt, Klauss Baumann, Christoph Jacobs, and Eckhard Frick. 2017. Spiritual dryness in Catholic priests: Internal resources as possible buffers. Psychology of Religion and Spirituality 9: 46-55. [CrossRef]

Büssing, Arndt, Yvonne Beerenbrock, Mareike Gerundt, and Bettina Berger. 2020. Triggers of spiritual dryness: Results from qualitative interviews with religious brothers and sisters. Pastoral Psychology. [CrossRef]

Cassidy, Jude, and Philip R. Shaver, eds. 2016. Handbook of Attachment, Third Edition: Theory, Research, and Clinical Applications. New York: Guilford Press.

Counted, Victor, Adam Possamai, and Tanya Meade. 2018. Relational spirituality and quality of life 2007 to 2017: An integrative research review. Health and Quality of Life Outcomes 16: 1-18. [CrossRef]

Davis, Edward B., Granqvist Pehr, and Carissa Sharp. 2018. Theistic relational spirituality: Development, dynamics, health, and transformation. Psychology of Religion and Spirituality. [CrossRef]

Davis, Edward B., Glendon L. Moriarty, and Joseph C. Mauch. 2013. God images and god concepts: Definitions, development, and dynamics. Psychology of Religion and Spirituality 5: 51-60. [CrossRef]

Degelman, Douglas, and Donna Lynn. 1995. The development and preliminary validation of the Belief in Divine Intervention Scale. Journal of Psychology and Theology 23: 37-44. [CrossRef]

Dein, Simon, and Christopher C. H. Cook. 2015. God put a thought into my mind: The charismatic Christian experience of receiving communications from God. Mental Health, Religion and Culture 18: 97-113. [CrossRef] [PubMed]

Dein, Simon, and Roland Littlewood. 2007. The voice of God. Anthropology and Medicine 14: 213-28. [CrossRef]

Dein, Simon, and Roland Littlewood. 2008. The psychology of prayer and the development of the Prayer Experience Questionnaire. Mental Health, Religion and Culture 11: 39-52. [CrossRef]

Exline, Julie J. 2013. Religious and spiritual struggles. In APA Handbooks in Psychology: APA Handbook of Psychology, Religion, and Spirituality: Vol 1. Context, Theory, and Research. Edited by Kenneth I. Pargament, Julie J. Exline and James W. Jones. Washington: American Psychological Association, pp. 459-75. [CrossRef]

Exline, Julie J. 2020. Anger toward God and divine forgiveness. In Handbook of forgiveness, 2nd ed. Edited by Everett L. Worthington Jr. and Nathaniel Wade. New York: Routledge, pp. 117-27.

Exline, Julie J., Joshua B. Grubbs, and Steffany J. Homolka. 2015. Seeing God as cruel or distant: Links with divine struggles involving anger, doubt, and fear of God's disapproval. International Journal of the Psychology of Religion 25: 29-41. [CrossRef]

Exline, Julie J., Steffany J. Homolka, and Valencia A. Harriott. 2016. Divine struggles: Links with body image concerns, binging, and compensatory behaviors around eating. Mental Health, Religion and Culture 19: 8-22. [CrossRef]

Exline, Julie J., Kenneth I. Pargament, Joshua B. Grubbs, and Ann Marie Yali. 2014. The Religious and Spiritual Struggles Scale: Development and initial validation. Psychology of Religion and Spirituality 6: 208-22. [CrossRef]

Exline, Julie J., Kenneth I. Pargament, Todd W. Hall, and Valencia A. Harriott. 2017. Predictors of growth from spiritual struggle among Christian undergraduates: Religious coping and perceptions of helpful action by God are both important. Journal of Positive Psychology 5: 501-8. [CrossRef]

Exline, Julie J., Crystal L. Park, Joshua M. Smyth, and Michael P. Carey. 2011. Anger toward God: Social-cognitive predictors, prevalence, and links with adjustment to bereavement and cancer. Journal of Personality and Social Psychology 100: 129-48. [CrossRef]

Fox, Jesse, Craig S. Cashwell, and Gabriela Picciotto. 2017. The opiate of the masses: Measuring spiritual bypass and its relationship to spirituality, religion, mindfulness, psychological distress, and personality. Spirituality in Clinical Practice 4: 274-87. [CrossRef]

Fox, Jesse, Daniel Gutierrez, Jessica Haas, and Stephanie Durnford. 2016. Centering prayer's effects on psycho-spiritual outcomes: A pilot outcome study. Mental Health, Religion and Culture 19: 379-92. [CrossRef]

Fox, Jesse, Gabriela Picciotto, Craig S. Cashwell, Everett L. Worthington Jr., Melissa J. Basso, Sarah Brow Corrigan, and Loren Toussaint. 2020. Religious commitment, spirituality, and attitudes toward God as related to psychological and medical help-seeking: The role of spiritual bypass. Spirituality in Clinical Practice 7: 178-96. [CrossRef]

Funder, David C., and Daniel J. Ozer. 2019. Evaluating effect size in psychological research: Sense and nonsense. Advances in Methods and Practices in Psychological Science 2: 156-68. [CrossRef]

Gignac, Gilles E., and Eva T. Szodorai. 2016. Effect size guidelines for individual differences researchers. Personality and Individual Differences 102: 74-78. [CrossRef]

Gilovich, Thomas, and Victoria Husted Medvec. 1995. The experience of regret: What, when, and why. Psychological Review 102: 379-95. [CrossRef]

Gleason, Marci E., and Masumi Iida. 2015. Social support. In APA Handbook of Personality and Social Psychology, Volume 3: Interpersonal Relations. Edited by Mario Mikulincer and Phillip R. Shaver. Washington: American Psychological Association, pp. 351-70. [CrossRef]

Granqvist, Pehr, Mario Mikulincer, and Phillip R. Shaver. 2010. Religion as attachment: Normative processes and individual differences. Personality and Social Psychology Review 14: 49-59. [CrossRef]

Hall, Todd W. 2015. Spiritual Transformation Inventory Technical Report: Development and Validation. Available online: www. spiritualtransformation.org (accessed on 9 November 2020).

Hall, Todd W., and M. Elizabeth Lewis Hall. forthcoming. Relational Spirituality: A Psychological-Theological Paradigm for Transformation. Downers Grove: IVP Academic, in press. 
Hall, Todd W., and Keith J. Edwards. 2002. The Spiritual Assessment Inventory: A theistic model and measure for assessing spiritual development. Journal for the Scientific Study of Religion 41: 341-57. [CrossRef]

Hall, Todd W., and Annie M. Fujikawa. 2013. God image and the sacred. In APA Handbooks in Psychology: APA Handbook of Psychology, Religion, and Spirituality: Vol 1. Context, Theory, and Research. Edited by Kenneth I. Pargament, Julie J. Exline and James W. Jones. Washington: American Psychological Association, pp. 277-92. [CrossRef]

Harriott, Valencia A., and Julie J. Exline. 2017. Perceptions of God's "voice." In Acts of God in the Mind, Body, and Soul. Chaired by Nick Stauner. Paper presented at Biannual Meeting of the International Association for the Psychology of Religion, Hamar, Norway, August 21-24.

Jones, Adam C., Rebecca Lucero Jones, and Neli Morris. 2018. Development and validation of the Couple Communication Satisfaction Scale. American Journal of Family Therapy 46: 505-24. [CrossRef]

Kirkpatrick, Lee A. 2005. Attachment, Evolution, and the Psychology of Religion. New York: Guilford.

Kuhn, Rebekka, Thomas N. Bradbury, Fridtjof W. Nussbeck, and Guy Bodenmann. 2018. The power of listening: Lending an ear to the partner during dyadic coping conversations. Journal of Family Psychology 32: 762-72. [CrossRef]

Ladd, Kevin L., and Bernard Spilka. 2002. Inward, outward, and upward: Cognitive aspects of prayer. Journal for the Scientific Study of Religion 41: 475-84. [CrossRef]

Ladd, Kevin L., and Bernard Spilka. 2013. Prayer: A review of the empirical literature. In APA Handbook of Psychology, Religion, and Spirituality (Vol 1): Context, Theory, and Research. Edited by Kenneth I. Pargament, Julie J. Exline and James W. Jones. Washington: American Psychological Association, pp. 293-310. [CrossRef]

Levine, Emma, Joanna Hart, Kendra Moore, Emily Rubin, Kuldeep Yadav, and Scott Halpern. 2018. The surprising costs of silence: Asymmetric preferences for prosocial lies of commission and omission. Journal of Personality and Social Psychology 114: 29-51. [CrossRef]

Luhrmann, Tanya M. 2012. When God talks back: Understanding the American Evangelical Relationship with God. New York: Alfred A. Knopf.

Mahoney, Annette. 2010. Religion in families, 1999-2009: A relational spirituality framework. Journal of Marriage and Family 72: 805-27. [CrossRef] [PubMed]

McLeod, Saul, Katherine Berry, Catherine Hodgson, and Alison Wearden. 2020. Attachment and social support in romantic dyads: A systematic review. Journal of Clinical Psychology 76: 59-101. [CrossRef] [PubMed]

Moriarty, Glendon L., and Louis Hoffman, eds. 2013. God image Handbook for Spiritual Counseling and Psychotherapy: Research, Theory, and Practice. New York: Routledge.

Pargament, Kenneth I., and Julie J. Exline. Forthcoming. Shaken to the Core: Spiritual Struggles in Research and Clinical Practice. New York: Guilford, in press.

Pargament, Kenneth I., Joseph Kennell, William Hathaway, Nancy Grevengoed, Jon Newman, and Wendy Jones. 1988. Religion and the problem-solving process: Three styles of coping. Journal for the Scientific Study of Religion 27: 90-104. [CrossRef]

Pargament, Kenneth I., Harold G. Koenig, and Lisa M. Perez. 2000. The many methods of religious coping: Development and initial validation of the RCOPE. Journal of Clinical Psychology 56: 519-43. [CrossRef]

Pargament, Kenneth I., Bruce W. Smith, Harold G. Koenig, and Lisa M. Perez. 1998. Patterns of positive and negative religious coping with major life stressors. Journal for the Scientific Study of Religion 37: 710-24. [CrossRef]

Poloma, Margaret M., and Matthew T. Lee. 2012. Prophetic prayer as two-way communication with the divine. Journal of Communication and Religion 35: 271-94.

Poloma, Margaret M., and Brian F. Pendleton. 1989. Exploring types of prayer and quality of life: A research note. Review of Religious Research 31: 46-53. [CrossRef]

Ray, Shanna D., Jennifer D. Lockman, Emily J. Jones, and Melanie H. Kelly. 2015. Attributions to God and Satan about life-altering events. Psychology of Religion and Spirituality 7: 60-69. [CrossRef]

Rowatt, Wade C., and Lee A. Kirkpatrick. 2002. Two dimensions of attachment to God and their relation to affect, religiosity, and personality constructs. Journal for the Scientific Study of Religion 41: 637-51. [CrossRef]

Smith, Christian. 2007. Is moralistic therapeutic deism the new religion of American youth? Implications for the challenge of religious socialization and reproduction. In Passing on the Faith: Transforming Traditions for the Next Generation of Jews, Christians, and Muslims. Edited by James L. Heft. New York: Fordham University Press, pp. 55-74. [CrossRef]

Spilka, Bernard, and Kevin L. Ladd. 2012. The Psychology of Prayer: A Scientific Approach. New York: Guilford.

Stauner, Nick, Julie J. Exline, Joshua B. Grubbs, Kenneth I. Pargament, David F. Bradley, and Alex Uzdavines. 2016. Bifactor models of religious and spiritual struggles: Distinct from religiousness and distress. Religions 7: 68. [CrossRef]

Wilt, Joshua A., Nick Stauner, Valencia A. Harriott, Julie J. Exline, and Kenneth I. Pargament. 2019. Partnering with God: Religious coping and perceptions of divine intervention predict spiritual transformation in response to religious/spiritual struggle. Psychology of Religion and Spirituality 11: 278-90. [CrossRef] 
Wilt, Joshua A., Joyce T. Takahashi, Dorothy Yun, Peter Jeong, Julie J. Exline, and Kenneth I. Pargament. Forthcoming. A mixed methods study of communing with and complaining to the divine: Imagined conversations with God among undergraduates. Psychology of Religion and Spirituality. in press.

Wood, Benjamin T., Everett L. Worthington Jr., Julie Juola Exline, Ann Marie Yali, Jamie D. Aten, and Mark R. McMinn. 2010. Development, refinement, and psychometric properties of the Attitudes Toward God Scale (ATGS-9). Psychology of Religion and Spirituality 2: 148-67. [CrossRef] 